\title{
Science and Morality: Mind the Gap, Use Happiness as a Safe Bridge!
}

\section{Review of "Exploring Happiness: from Aristotle to Brain Science" by Sissela Bok, Yale University Press, New Haven and London, 2010, ISBN 978-0-300-13929-7}

\section{Jan Ott}

Published online: 21 March 2012

(C) The Author(s) 2012. This article is published with open access at Springerlink.com

\begin{abstract}
In 2002 Sissela Bok re-published her book "Common Values", first published in 1995, about her search for a minimal set of values to be respected all over the world. In her view such a set of values is needed to facilitate international communication and cooperation. Values already recognized in every society can be included as a starting point. In her book "Exploring happiness", published in 2010, she explains why she finds happiness unfit to be included. She observes that there are discordant claims about what happiness is. Any particular vision can lead to practical choices that either adhere or violate the values she prefers. In my view subjective happiness should be included, because there are no discordant claims about the meaning of subjective happiness, and subjective happiness is simultaneously attractive as a moral value and as an object of scientific research. Subjective happiness can function as a bridge between science and morality. The only discordant claims are about 'objective' happiness, as a wider interpretation of well-being in the context of some specific morality or ideology.
\end{abstract}

Keywords Empirical research · Happiness - Morality - Objective happiness · Science $\cdot$ Subjective happiness $\cdot$ Values

\section{Introduction}

Sissela Bok is a moral philosopher and fellow of the American Academy of Political and Social Science. In 2002 she re-published her book "Common Values" (1995) about her search for values to be respected all over the world. ${ }^{1}$ In her view such values are needed to

\footnotetext{
1 Bok presents no definition of a value but apparently uses it in the usual way, like in this definition by Shalom Schwartz: 'desirable trans-situational goals, varying in importance, that serve as guiding principles in the life of a person or other social entity' (Schwartz 1994). The Dutch sociologists van Doorn and Lammers (1968) present a comparable definition: "A central standard to evaluate one's own behavior or the behavior of other people". These sociologists see happiness primarily as a goal or something people actually
}

J. Ott $(\bowtie)$

Erasmus University Rotterdam, Rotterdam, The Netherlands

e-mail: jan.ott@planet.nl 
facilitate international communication and cooperation. She finds that some values can be recognized in every society. These values can be included in a minimal set of common values at a mondial level. Such a minimal set can be a starting point for the development of more values and leaves enough room for cultural diversity. She finds that the following values should be incorporated:

- Basic forms of mutual support, loyalty, reciprocity

- No harmful action (curbs on deceit, violence, and betrayal)

- Minimal fairness and procedural justice to solve conflicts

In her latest book "Exploring Happiness" (2010) Bok considers happiness as a potential common value. Her view is rather critical, because there are discordant claims about what happiness is. Any particular vision can lead to practical choices that either adhere or violate the values she prefers. One example she mentions: the al-Qaeda pilots who guided the planes into the World Trade Center had been promised everlasting happiness in a future paradise, and their relatives were happy about their success. Sissela Bok prefers the values just mentioned and she also has more sympathy for the values proposed by Immanuel Kant: good will, character, and doing what duty calls for (Kant 1785).

Bok's argument is interesting, but only valid for 'objective' happiness and not for 'subjective' happiness. There are no discordant definitions for subjective happiness, it is always defined as the appreciation of ones own life as a whole or in a very similar way. Subjective happiness is attractive as a moral value - to be included in Bok's selectionand simultaneously as an object of empirical research. I will first summarize Bok's views, with a few comments in footnotes, and then specify my arguments.

\section{Bok's Book: Discordant Definitions of Happiness}

Bok presents several definitions of happiness with some leading questions like the following:

- Are people the best judges of their own happiness?

- To what extent are virtue and happiness conceptually linked? Is virtue necessary and/or sufficient for happiness?

These questions are not independent. People are no adequate judges of their own happiness if virtue is supposed to be a necessary ingredient. Definitions that incorporate virtue are 'objective' at that point. The definition of happiness by Aristotle is a famous example: “... the soul's activity that expresses virtue". 2 Since reason is another important ingredient for Aristotle, Bok observes that Sara Broadie usefully proposes a compact formula for Aristotle's conception: "The rational soul's activity of virtue in a complete life" (Broadie

Footnote 1 continued

pursue. In my view happiness can function as a goal and as a value: as something people actually pursue or as something they find important without practical consequences for their behavior. In theory we can make a distinction between values in general and moral values: altruistic values unrelated to any interests of specific persons or groups. In my view this distinction is useless since any value can be used in an altruistic way, or to promote or defend specific interests.

2 Nowadays Aristotle's' 'eudemonia' is usually translated as (objective) 'well-being' or 'human flourishing'; but this is irrelevant for the discussion at this point (Brülde and Bykvist 2010). 
2007). In this view, as Bok observes, 'a happy torturer' would be a contradiction in terms. ${ }^{3}$ Epicurus, Seneca and Thomas Jefferson hold similar views.

There are more qualifications that can be incorporated into the definition of happiness. According to John Rawls happiness must be based on a rational life-plan (Rawls 1999). Immanuel Kant incorporates rationality but leaves out virtue, as a first step to reject happiness as the supreme good and putting in its place doing one's duty. His definition of happiness: "a rational being's consciousness of the pleasantness of life uninterruptedly accompanying his whole existence". In his view people have to deserve happiness by doing their duty. If they do their duty they will be rewarded with happiness, if needed in afterlife.

Such incorporations of 'objective' criteria, like virtue and rationality, are absent in 'subjective' definitions where people are supposed to be the best judges of their own happiness. ${ }^{4}$ Richard Layard, invoking Jeremy Bentham, defines happiness as "feeling good-enjoying life and wanting the feeling to be maintained." (Layard 2005). Ed Diener contrasts such conceptions to the traditional focus on objective criteria: It is this approach to defining the good life that has come to be called 'subjective well-being' (SWB) and in colloquial terms is sometimes labelled 'happiness' (Diener 2000). In this subjective happiness there are two components to be discerned: affect and cognition. Bok cites some definitions again like the one by Wayne Sumner: "Happiness or life-satisfaction is a positive cognitivelaffective response on the part of a subject to (some or all of) the conditions or circumstances of her life" (Sumner 2000).

Bok does not prefer any definition in particular. She appreciates diversity in definitions and believes that different definitions represent differences in felt happiness. Such differences should not be blocked out because then we might slip into "... unreflective, onedimensional conclusions about the extent to which marriage, for example, or religious beliefs or health, correlates with happiness" (p. 33).

About the objective and subjective views she makes the following remarks: "... while I believe that the subjective experience of happiness must have priority, I take both the insider's and the outsider's perspectives to be needed for fuller understanding. Each can help counteract errors and biases in the other. Those who take only a person's own experience into account are as prone to such errors and biases as those who focus only on objective indications of people's preferences and needs. Even as we adopt either the subjective or the objective perspective, we should not lose sight of the other." (p. 43)

\section{My Comments: the Moral and Scientific Attractiveness of Subjective Happiness}

In Bok's view both the subjective and the objective perspective are needed for an adequate understanding of happiness. This view makes sense in moral and political discussions, but we must observe that subjective happiness is more suitable as an object of empirical research. In addition to that we must observe that the results of such research can play a role in moral and political discussions. We may discern two ways to improve the quality of such discussions:

\footnotetext{
${ }^{3}$ Correct, but perhaps Aristotle's own view would be different if this torturer would be a rational Greek man and his victim a hostile Barbarian!

4 There are definitions that incorporate objective and subjective elements simultaneously but such definitions are exceptional; probably because such a mixture is neither one thing nor the other.
} 
- philosophical reflection on the pros and cons of values, and

- empirical research on values, their acceptance, their actual realization, and their interactions.

In my view both ways are valuable, but Bok seems to underestimate the importance of the second approach. I will pay attention to the definition of subjective happiness first, before I present my view that subjective happiness is simultaneously attractive as a moral value, even if virtue and morality are left out of the definition, and as an object of scientific research.

\subsection{The Definition of Subjective Happiness}

Bok refers to the definition by Wayne Sumner: "Happiness or life-satisfaction is a positive cognitivelaffective response on the part of a subject to (some or all of) the conditions or circumstances of her life". This definition comes close to definitions usually used in empirical research, e.g.: happiness as the appreciation of life, as reported by the people themselves, spontaneously or after some reflection. This general or overall happiness ${ }^{5}$ is based on two components:

- affective happiness, primarily based on mood, ${ }^{6}$

- cognitive happiness, primarily based on reflection and cognition. ${ }^{7}$

This conceptualization is proposed by Veenhoven (2011) and is applied in the World Data Base of Happiness. There can be a difference between the affective and cognitive component, because one can be in a good mood most of the time but still judge that life falls below one's standards, and the other way around. The two components and overall happiness are nevertheless highly correlated, probably as a result of intensive interaction. ${ }^{8}$

5 One way to measure overall happiness: "All things considered, how satisfied are you with your life as a whole these days?" Please use this card to help you with your answer:

12345678910

(Dissatisfied $>$ Satisfied)

Source: Inglehart, R.; World Values Surveys and European Values Surveys (http://www.worldvalues survey.org)

In this question the appreciation can be based on emotions and moods, but also on cognition.

${ }^{6}$ One way to measure the affective component directly is the Day Reconstruction Method. People are asked to report about their emotional experiences of the previous day. An alternative method, not mentioned by Bok, is the Affect Balance Scale, as developed by Norman Bradburn, where people are invited to report about specific positive and negative moods and emotion in the past few weeks. In the Experience Sampling Method, also used by Kahneman (1999), people are invited to report about there emotions and moods immediately without reflection (Csikzentmihalyi and Larson 1987). This method is expensive since many measurements are required to develop a representative picture. Emotions and moods can also be identified with brain research but only in a rather crude way.

7 One way to measure the cognitive component directly is developed by Cantril (1965): Suppose we say that the top of the ladder represents the best possible life for you and the bottom of the ladder represents the worst possible life for you. Where on this ladder do you feel you personally stand at the present time? Please use this card to help you with your answer.

012345678910

(Bottom of the ladder $>$ Top of the ladder). This question is rather cognitive because it almost invites people to disregard their emotions and moods. This question is used in the Gallup World Poll (http://www.gallup.com/consulting/worldpoll).

${ }^{8}$ In 2006 there is a significant correlation of +0.46 between positive feelings in nations (affective happiness) and average contentment with life in 128 nations as measured with a ladder-scale (Data Gallup World Poll). 


\subsection{The Attractiveness of Subjective Happiness as a Value}

Accepting or rejecting subjective happiness as a value is obviously not a scientific decision but eventually a moral choice. There are however some considerations in favour of subjective happiness as a value.

One consideration is that happiness is about the appreciation of people of their own life, and not, as in 'objective' happiness, about the appreciation by any outsider. Granting subjective happiness the status of a value is therefore consistent with respect for individual autonomy and freedom. In average happiness the happiness of anybody gets the same weight, just like anybody's vote in democratic elections. It is interesting to notice at this point that democracy and subjective happiness have a similar attractiveness as values: both combine fitness for research with respect for equality and self-determination.

One interesting result of happiness research is the finding that, whatever the goals people pursue, an active life and individual efforts contribute substantially to happiness. We may conclude therefore, that even if we prefer alternative goals we may still appreciate happiness as a positive by-product of such efforts. Happiness has also some appreciated consequences: it has a positive impact on health (Veenhoven 2008) and happy people are more willing to participate in public activities and are less apt to engage in obstructive behaviour (Guven 2009). In sum: even if we prefer alternative goals we can still appreciate happiness as a pleasant ingredient and consequence of our ambitions.

Subjective happiness should nevertheless never be cherished in some uncritical way. Individual happiness can be immoral if it is based on accepting or creating misery, as in criminal behaviour. With average happiness this is less likely because immoral behaviour has in many cases a negative impact on average happiness. Even average happiness however, can be based on immoral behaviour towards specific individuals, other groups, nations, animals, or future generations.

\subsection{The Attractiveness of Subjective Happiness as an Object for Empirical Research}

Subjective happiness is very appropriate as an object in empirical research, because it can easily be matched with observations. Earlier research has established that people all over the world think about their life and develop some appreciation of their life. They are also able to answer questions about this appreciation, with sufficient levels of reliability and validity (Veenhoven 2010).

Any incorporation of additional conditions in the definition, like virtue or rationality, creates an 'objective' definition and makes it difficult to assess happiness. Defining subjective happiness as just the appreciation of life also facilitates the analysis of the relations between happiness and potential determinants, e.g. virtue and rationality, but also wealth, freedom, gender equality, public healthcare, safety, rule of law, and democracy (Ott 2010). Such relations disappear 'out of sight' if such determinants are incorporated into the concept.

There are more values that can be matched with observations, but for many values this is rather complicated. It is certainly complicated for virtue, rationality, solidarity, justice and doing one's duty, because the actual interpretation of such values depends heavily on specific cultural contexts. It is also difficult for the values Bok prefers: curbs on deceit (honesty, truthfulness), curbs on violence, and betrayal; and basic forms of reciprocity and nurturing.

If values cannot be matched with observations it will be relatively easy to manipulate the interpretation of such values, because it is difficult to organize relevant empirical feed back. 'Doing one's duty', and the happiness for the al-Qaeda pilots in some future paradise, are typical examples. 


\section{Conclusion: Happiness as a Safe Bridge Between Science and Morality}

Bok underestimates the importance of empirical research for discussions about moral issues. She finds that empirical research is inclined to put priority on observable phenomena, and to neglect the meaning and values people attribute to such phenomena. True, but "it ain't necessarily so", and empirical research is urgently required to assess the actual acceptance of values, their realization in practice, and their mutual relations.

Bok would probably have been more positive about subjective happiness as a common value if she would have paid more attention to the gap between science and morality: two different worlds without natural bridges in between. Philosophers like Hume (1739) and Popper (1945) have made it very clear that crossing this gap requires some careful attention. ${ }^{9}$ The gap is visualized in Table 1 .

Table 1 is about four different questions: (1) Should a value be accepted? (2) Do people accept this value? (3) Is this value realized in practice? and (4) Is this value compatible with alternative values? Discussions about the first question are about morality, discussions about the next questions are about science and empirical research. For happiness: (1) Should we, as observers, policy-makers, or people in general, accept happiness as a value? (2) Do people accept happiness as a value? (3) Are people happy? (4) Is happiness compatible with alternative values, e.g. honesty, non-violence, justice, sense of duty, altruism and freedom? For happiness it is relatively easy to answer the second and third question because people can just rely on their personal experience in answering questions about their-subjective!- - happiness. For alternative values this is usually more complicated, because there is more cultural and individual variety in interpretations. The answers to the second and third question can be used to answer the fourth question; in as far as the alternative values are-nevertheless-fit for research. The answers to the empirical questions 2, 3, and 4 can be used as additional considerations in moral discussions about the first question. Subjective happiness is therefore rather unique, as a safe man-made bridge to cross the gap between science and morality.

Table 1 Values, their acceptance, their realization and their compatibility

\begin{tabular}{|c|c|c|c|c|c|c|c|c|}
\hline \multirow[t]{2}{*}{ Values $\mathrm{X} 1, . . \mathrm{Xn}$} & \multicolumn{2}{|c|}{$\begin{array}{l}\text { 1. Should X be } \\
\text { accepted? }\end{array}$} & \multicolumn{2}{|c|}{ 2. Is X accepted? } & \multicolumn{2}{|c|}{$\begin{array}{l}\text { 3. Is X realized in } \\
\text { practice? }\end{array}$} & \multicolumn{2}{|c|}{$\begin{array}{l}\text { 4. Is X } \\
\text { compatible } \\
\text { with ....? }\end{array}$} \\
\hline & Yes & No & Yes & No & Yes & No & Yes & No \\
\hline $\mathrm{X} 1$ & & & & & & & & \\
\hline $\mathrm{X} 2$ & & & & & & & & \\
\hline X3 etc. & & & & & & & & \\
\hline
\end{tabular}

\footnotetext{
9 Hume (1739) made a clear distinction between 'is' and 'ought' and observed that it is not obvious how to get from descriptive statements about facts to prescriptive statements about values and norms. Popper (1945) pays attention to accidents that can happen if this distinction is neglected. One well-known example: Soviet regimes putting dissidents in mental hospitals to improve their 'understanding of history and the inevitability of communism'.
} 
Open Access This article is distributed under the terms of the Creative Commons Attribution License which permits any use, distribution, and reproduction in any medium, provided the original author(s) and the source are credited.

\section{References}

Bok, S. (1995). Common values. Columbia, MO/London : University of Missouri Press.

Broadie, S. (2007). Aristotle and beyond: Essays on metaphysics and ethics. New York: Cambridge University Press.

Brülde, B., \& Bykvist, K. (2010). Happiness, ethics, and politics: Introduction, history and conceptual framework. Journal of Happiness Studies, 11, 541-551.

Cantril, H. (1965). The pattern of human concern. New York: New Brunswick.

Csikzentmihalyi, M., \& Larson, R. (1987). Validity and reliability of the experience sampling method. Journal of Nervous and Mental Disease, 175(9), 526-536.

Diener, E. (2000). Subjective well-being: The science of happiness and a proposal for a national index. American Psychologist, 55(1), 34-43.

Guven, C. (2009). Are happier people better citizens?. Australia: Deakin University.

Hume, D. (1739). A treatise of human nature.

Inglehart, R. World values surveys and European values surveys. http://www.worldvaluessurvey.org.

Kahneman, D. (1999). Objective happiness. In E. Diener, N. Schwartz, \& D. Kahneman (Eds.), Well-being: The foundations of hedonic psychology. New York: Russell Sage.

Kant, I. (1785). The groundwork of the metaphysics of morals.

Layard, R. (2005). Happiness: Lessons from a new science. London: Penguin Books.

Ott, J. (2010). Government and happiness in 130 nations: Good governance fosters higher level and more equality of happiness. Social Indicators Research, 102(1), 3-22.

Popper, K. (1945). The open society and its enemies.

Rawls, J. (1999). A theory of justice, revised edition. Cambridge, MA: Harvard University Press.

Schwartz, S. (1994). Beyond individualism/collectivism: New cultural dimensions of values. Individualism and collectivism: Theory, method, and applications. Thousand Oaks, CA: Sage Publications.

Sumner, W. (2000). Something in between. In R. Crisp \& B. Hooker (Eds.), Well-being and morality: Essays in honour of James Griffin. New York: Oxford University Press.

Van Doorn, J., \& Lammers, C. (1968). Moderne Sociologie. Utrecht/Antwerpen: Het Spectrum.

Veenhoven, R. (2008). Healthy happiness: Effects of happiness on physical health and the consequences for preventive healthcare. Journal of Happiness Studies, 9(3), 449-469.

Veenhoven, R. (2010). How universal is happiness? Chapter 11. In E. Diener, J. Helliwell, \& D. Kahneman (Eds.), International differences in well-being. New York: Oxford University Press.

Veenhoven, R. (2011). Measures of happiness (Item bank). World Database of Happiness, Erasmus University Rotterdam. Assessed May 2011 from http://www.worlddatabaseofhappiness.eur.nl/ hap_quer/hqi.htm. 